Civic Review, Vol. 15, Special Issue, 2019, 416-425, DOI: 10.24307/psz.2020.0226

Balázs Cseh

\title{
The History of Public Business Organisations in Hungary - Reflections Taking Further the Logic of the Book East of Europe, West of Asia
}

SUMMARY

The purpose of this study is no more than to give a brief summary of the history of business organisations in public ownership in Hungary along the logic of a recently published large monography. Using the method of descriptive historical approach, facts are established as a result of a kind of syncretistic literature overview. As a basic idea, with a view to the "Sitz im Leben" approach, the evolution of public business organisations may be compared to the development of public finances, and should be managed embedded in the latter, similarly to the economy, which always functions embedded in the society.

Journal of Economic Literature (JEL) codes: B10, G01, N10, P10, P20, Y3
Keywords: public finance policy, public utility and public business organisations, Austro-Hungarian Monarchy, socialist planned economy, transition to a market economy, Hungary

INTRODUCTION

Public business organisations have a relatively short history in Hungary. Their development can be analysed since the 19th century. In my opinion, the existence of public business organisations as peculiar legal entities should be compared to the development of Hungarian public finances as they are closely and inalienably related to state finances and the general government. Due to this interrelationship, on the review horizon I describe the overall public finance environment of

Dr BalÁzs Cseh, lawyer, economist, theologian, PhD student, Public Administration Doctoral School of the National University of Public Service (cseh.balazs1990@ gmail.com). 
the given era, as a background to public business organisations and the hotbed of their existence and operation.

The evolution of public business organisations may not look back to times before the appearance of business organisations and their regulation by Hungarian company law, as the establishment of business organisations presupposes that of public business organisations. This follows from their conceptual definition, as under the currently effective statutory regulations, a publicly owned business organisation is nothing else than "a business organisation in which the Hungarian State, a local government, a local government's partnership having legal personality, a multi-purpose micro-regional council, a development council, a minority government, a minority government's partnership having legal personality, a budgetary organisation or a public foundation have majority control, either separately or jointly." I have performed all this along the logic of and reflecting, among others, on two monographies by Csaba Lentner. ${ }^{2}$

\section{Between the 19TH AND THE SECOND HALF OF THE 2OTH CENTURY}

As Tekla Papp also correctly establishes, the first, perhaps somewhat weak, initiatives taken for the codification of Hungarian company law started with Act XVIII of 1840 (Papp, 2000). Of the corporations relevant for our topic, the joint stock company was first defined in this act (in addition to general partnerships and limited partnerships), and has remained one of, and also the most characteristic, legal forms of public companies ever since then. However, this legislation merely outlined a rudimentary formation of a joint stock company, which was unsuitable for construing the foundation of public businesses. The merit of this work is that it can be considered as the very first codification in Hungarian company law, which remained in effect up to the entry into force of the monumental Trade Act (which entered into force on 1 January 1876), in other words, up to the period after the Compromise. In 1867, nearly two decades of opposition and lengthy negotiations, the compromise between Austria and Hungary was born with Act XII of 1867. The Austro-Hungarian Monarchy, a state with two centres, which was established at that time, meant the alliance of two legally equivalent states. Common affairs included foreign affairs, military affairs and especially - perhaps most importantly, as, to quote General Raimondo Montecuccoli, "War requires three things: money, money and money" - finances, required to provide coverage for the first two. Csaba Lentner points out that the Compromise marked the beginning of some fifty years of a spectacular economic development (Lentner, 2019), and this is consistent with a similar assertion by historian Dániel Szabó (Szabó, 2001). That period already saw the appearance of significant economic thinkers, like Széchenyi, Wesselényi and Bezerédj, and specialised policy-makers managing finances, like Ferenc Duschek. Both Ernố Huszti (2001) and Lentner (2019) recognise this statesman's conceptual achievements in public finances.

The majority of finance ministers after the Compromise appropriately managed financial policy as well as the executive apparatus, but three personalities, Menyhért Lónyai, Kálmán Széll 


\section{Academic Workshop and Book Reviews}

and Sándor Wekerle, stand tall among them (Lentner, 2017). Their knowledge, professional grounding and managerial skills were extremely high-standard, and it was no accident that all the three were also academicians, as recognised by Gábor Hamza (2015). The first public business organisation, the Hungarian state railways, which celebrated the 150 years anniversary of its incorporation recently, was established in this period. After 1846, exclusively privately owned railways operated in Hungary, disregarding a short period between 1850 and 1855, when the management in Vienna was considering state-owned railways. By 1855, the Austrian state treasury had been completely exhausted by the operation of state-owned companies; railways were once again given into private ownership. Then the wise Hungarian government realised the importance of a public holding strategy, and in 1868 it took a significant part of the railways into state ownership, and then in 1869 it established the Hungarian Royal Railways in the form of a joint stock company. This state-owned joint stock company continued its unbroken development up to World War I, and by the way, the company made profits. The other successful state-owned company was the strategically important Hungarian River and Maritime Navigation Limited (Suba, 2018). As a preliminary, mention should be made of the fact that the Danube Steamboating Company, established in 1829 , had monopoly up to 1858 . At the recommendation of István Széchenyi, this shipping company built the largest shipyard in Óbuda. For a long time, this was Hungary's largest industrial plant, which introduced a new work style, working methods and occupations with English contribution along the River Danube. After the 1867 Compromise, Hungarian national economic concepts and interests could be increasingly enforced within the Austro-Hungarian Monarchy. One such important transport-related business interest was breaking the predominance of D.G.T. in shipping by the establishment of an independent, state-owned shipping company that served Hungarian interests. In terms of public finances, this joint stock company could only be established from the reserve of the Hungarian Discount and Exchange Bank. However, this financial institution was Hungarian only in its name, as there was no independent Hungarian central bank at that time, and it met Hungarian companies' demand for external resources and acted as a lender to the government in a period when the one-tier banking system under the control of foreign capital (Kövér, 1992). The drawbacks of the liberal money management and allocation, characteristic of the time, are comparable to the recent past I mean the period of history immediately preceding 2010.

The significance of state-owned companies in the national economy was particularly illuminating during the Great War, and then the period reviewed in this study falls between the two World Wars. state-founded and state-owned Workers' National Patient Support and Casualty Insurance Fund, which entered the market of insurers and provided insurance products citizens could initially use on a voluntary basis. On the other hand, the state-owned shipping company continued operation as an exemplary company, ensuring a peculiar ethos for its employees and was surrounded by general social recognition (Szávai, 2017). However, it 
is important to note - and I agree with Csaba Lentner's assumption - that the most important, landmark action taken in the financial and economic field in this period was the establishment of the National Bank of Hungary on 26 April 1924 and the setting up of independent monetary administration. Undoubtedly, this wise government decision has the highest impact on Hungary's current finances (Lentner, 2019). A similar conclusion is made by Károly Bognár (1994). In the life of the profitable and developing state-owned companies, the processes triggered by the 1920 Peace Treaty of Trianon - specifically, the damage caused to Hungary's territory, population and economy, which reduced Hungary to the smallest, economically and militarily weakest and, due to the international constraints, the most vulnerable country in Hungary's surroundings - caused drastic changes, and the government responded by their reorganisation, but without reducing state contribution, as it recognised that the state had an outstanding role in the national economic strategy. As a result of changes in the borderline, the country's economic structure was fundamentally re-arranged. The remaining economic structure became disproportionate, development halted and these trends were further increased by the mutual isolation policy. The previously uniform market was replaced by new customs borders, customs tariffs and economic policies.

The key characteristic feature of the early years in the period was that after several centuries of "limited independence", the country regained and created it sovereignty in every respect. In order to establish financial stability, a new na- tional currency, the pengó was issued. The primary task of the first few years was stabilisation: the framework of the country's operation had to be set up and re-shaped, the internal and external political and economic relations had to be re-organised and the national currency had to be created. Lentner correctly recognises that the economic consolidation and the stability of public finances may be best related to Prime Minister István Bethlen; however, he critically notes that the statesman should not be placed on a pedestal (Lentner, 2019). The country successfully stabilised the economy, society and the political institutions, and despite difficult circumstances, by 1929 the national income had increased by 10 per cent, while an impressive economic growth had been achieved relative to the low point seen after World War I.

The defensive economic policy of the era, increase in state holding and ownership, and strengthening Hungarian working capital increased the number and weight of state-owned companies: state-owned industrial factories were established one after the other, and the hotel business, recreational and spa facilities flourished. However, the 1929-1933 global economic crisis broke the impetus of development and contained companies' opportunity to operate. Financial problems were encountered in Hungary in 1931, but already in the previous years, several countries in the region had accumulated short- and long-term debt, and primarily American and British lenders, who did not feel safe, started to withdraw their loans, causing serious payment problems to the state. In 1931 the disclosed collapse of the huge Viennese bank Creditanstalt further accelerated 
the process. The purchase of foreign currency by Hungarians increased and significantly reduced the central bank's currency and metal stocks - similarly to the developments seen during the 20072008 crisis. Hungarian financial institutions, with ownership and shareholder structures already showing signs of increasing state role, satisfied all demand that were made, and nevertheless, the risk of panicky deposit withdrawal was threatening, and did actually take place in Bucharest, Sophia, Athens and Germany. Bank closure could not be maintained for a long time, since not only payments were not transacted but taxes were also not collected and wages could not be disbursed either. In 1933, the nominal value of the national income dropped to 55 per cent of the corresponding 1929 figure, and even in 1938 it only exceeded the pre-crisis level by 7 per cent. As a result of the crisis, austerity measures were taken, e.g. public servants' salaries were reduced significantly, and as this hindered state operation - and the functioning of state-owned companies, which were major employers -, it also impeded the government's crisis management. The economy of the new Hungarian state proved to be vulnerable. In 1937-1938 the per capita national income was about USD 120 or 130 of the time, amounting to approximately 60 per cent of the average of Europe. Starting from 1924, foreign capital came in the form of short- and long-term loans, and was then followed by a major influx of working capital into the industry. Primarily American, British, German and, to a lesser extent, French capital bought interest in the Hungarian economy. In 1929, the ratio of foreign capital was 28 per cent, which gradually decreased to merely 24 per cent in 1938 . After the outbreak of the war, due to German economic penetration, the share of foreign capital increased again. Drawing conclusions from the experiences of the crisis of the time, Lentner cautions against attracting extensive foreign direct investment, borrowing from abroad and exposing the Hungarian national economy (Lentner, 2002; 2016; 2019).

\section{SECOND HALF OF THE 2OTH CENTURY}

After World War II, Hungary was excluded from western financial modernisation for a long time. Our region was placed under the influence of the Soviet Union, which liquidated the market economy built on private ownership and forced its own social and economic system of a "collective dimension" on the countries of the region. For example, in 1946 the above-mentioned state-owned shipping company was liquidated and a Hungarian-Soviet shipping company (MagyarSzovjet Hajózási Rt.) was established, which was subsequently replaced in 1955 by the Hungarian shipping company (Magyar Hajózási Rt.), which has been attending to river and maritime navigation, operating and supervising harbours since then. The harmonic and balanced coexistence of public and private business organisations was disrupted. In fact, only the banks taken into state ownership (National Bank of Hungary and the Hungarian Commercial Bank of Pest) and foreign trade companies (e.g. Export Trade and Goods Purchase Ltd. and the Hungarian Foreign Trade Ltd.) operated in the form of commercial businesses, for the most part as joint stock companies and only an insignificant number of them were lim- 


\section{Academic Workshop and Book Reviews}

ited liability companies (Perbíró, 1950). The annihilation of the institutions of civil society, private capital, private companies and the private market, or their reduction to purely formal entities, was accompanied by the confinement of market economy ("money economy") at the end of the 1940's. Economic procedures were replaced by the planned economy regime. Law-decree No. 20 of 1949 ordered the taking of medium-sized industrial companies and enterprises in state ownership. This action also required the establishment of a new kind of controlling organisation due to the large number and diversity of companies. Decree No. 102/1950. (IV.4.) Mt. fulfilled this demand by subjecting state-owned companies to control under an association (Papp, 2000). Lentner (2019) gives a critical description of the poor finance policy of the period; however, his critical tone does not contain exaggerated catchphrases or unreasonably sharp remarks. Katalin Botos (2007) also recognised and highlighted the fact that social tensions were traceable not simply to economic difficulties. With this assumption she refines Gremuska's findings. Gremuska does not draw a dividing line between the Rákosi and the Kádár regimes (Germuska, 2012), in contrast, Lentner (2019) demonstrates that there are essential differences between the finance policies of these two periods, and ascertains that from the late 1960's, Hungary moved towards the implementation of a planned economy saturated with market elements and giving residents every chance to succeed. Due to domestic political efforts at restauration and the displeasure of the soviet political leadership, supported by foreign political and military pressure, this transformation could not be completed, however, it provided a good basis for start of transition to a market economy at the end of the 1980's, although opportunity for the latter was, for the most part, seen in the attraction of external market participants to Hungary. I agree with Lentner who compares the downfall of Hungary's own method of planned economy mostly with the failure of the 1968 reform efforts (Lentner, 2019). In addition to state companies having a homogeneous and monopolistic role, this period was characterised by the fact that the Finance Ministry merely administered financial transactions, as planning was given priority and money was assigned a passive role. Pricing was applied in the planned economy, but indicating relative shortage was not included among the primary tasks of the price regime. Factories did not produce because goods had low prices, as prices were essentially set by the authorities, who also decided in any other matter. For this very reason, in the case of state companies, profitability or efficiency were excluded and not applicable. Although public business organisations have the most profound role in the People's Republic of China, and Chinese public business organisations are in the focus of research and the international literature, they significantly differ from the public companies that were operative in the People's Republic of Hungary (Milhaupt, 2020). This goes to show that the state companies of those days and the current ones should not be blurred, despite the fact that the same expression is used when they are referred to, as we can squarely state that differences between them can be demonstrated in everything else. 


\section{Academic Workshop and Book Reviews}

In the period of transition to a market economy, in other words, between the change of regime and the turn of the millennium, a compulsive assertion of the correctness of the government's financial decisions was a constant practice. In this respect, Erzsébet Gidai (1996) was of the opinion that the largest obstacle to financial stability was external indebtedness. The assumptions that Hungary would be raised by the influx of direct investment and that its government deficit could be offset by new borrowing can be considered incorrect. Moreover, they urged the privatisation of nearly the total amount of assets held by the state, and complete termination of all the companies in state ownership, and they wished to accomplish the full annihilation of the government's role. One of the decisions that can be considered especially flawed - mainly in the case of state-owned companies - was the promotion of the philosophy underlying the Washington Consensus, which says that the state should withdraw from economy influencing and the government's role should be reduced in order to create a vigorous, efficient and successful market economy, or to put it in another way, the neoliberal economic policy that characterised the 1990's (up to 1998) in Hungary. In contrast, György Matolcsy (1998) recognised as early as 1998 that there was a need for the state to undertake a greater role, and so state ownership should be increased in the strategic sectors. Using a perfect and neat argumentation, Lentner (2019) demonstrates the misguided political decisions that resulted in Hungary's significant exposure to the 2007-2008 global economic crisis. These did not include the decisions adopted to consolidate finances and stabilise the economy in the period between 1998 and 2002. We have to agree with Csaba Lentner and Nobel Prize awarded economist Joseph E. Stiglitz, who think that the macro-economic models used by neoclassical economics were unsuitable for forecasting crises; they were built on flawed premises, and unreasonably justified an even supply of information and that stakeholders always made reasonable decisions. In Stiglitz's opinion the absence of an appropriate theory also misleads economic decision-makers and triggers crises. Lentner traces back Hungary's crisis to these misguided decisions, and concludes in addition that the decisions made by the various governments between 2002 and 2010 blindly followed the neoliberal market economy model, and consequently, innovation in banking products was not followed by innovation in the supervisory and regulatory regimes, which led to the unfolding of a crisis not only in mortgage lending but also in the entire neoliberal economic regime, as also believed by Tibor Tatay and Krisztina Szegedi (Lentner et al., 2017). We should agree with the claim that the first step on the road leading out of the crisis was increasing the role of the government (Lentner, 2019), consequently the strengthening of public business organisations, especially the repurchase of the shares in MÁV (the Hungarian State Railways), the acquisition of shares in MOL (the Hungarian oil company) or the establishment of an increasing number of waste management companies in local government and the state ownership, and increasing the state's share in the energy market (district heating, Paks Nuclear Power Plant etc.). 
In addition to increasing state ownership in companies operating in strategic sectors, increasing the number of public companies and their role in the economy, favourable developments took place in fiscal policy, including the placing the Hungarian tax regime on a new footing after 2010. The principal elements in this change included a change in the structure of taxation, through reducing taxes on labour and capital while simultaneously increasing taxes on consumption (Varga, 2017), which improved the efficiency of public companies' operation. Legitimisation of the tax system and the entire economy and the reduction of the shadow economy have turned general distrust in public business organisations and the opinion that they were the hotbeds of corruption and the embezzlement of public funds. The efficient and successful controlling and supervisory role of State Audit Office had no small part in this, as by statutory authorisation, it has regularly audited state- and local government-owned business organisations since 2011. Another major contribution was the incorporation of elements like the ideas represented by leading economists György Matolcsy (2016) and Domokos László (2015) in thinking about public finance. With the restoration of the institutional approach and with the appreciation of transparency, a public finance management approach, unconventional economic policy and illiberal economic thinking, a new era commenced in the operation of public (government and local government-owned) business organisations. For this reason, these companies have become the engines of economic growth, and as the professor puts it: "If there is growth, and financial balance underlying growth, and if companies and employees are interested in expanded reproduction, economic policy leads to success" (Lentner, 2019, p. 250). The most recent milestone in the favourable trend seen after the crisis is the amendment of Act CXXII of 2009 on the more economical operation of business organisations in public ownership, which affects most businesses in local government or state ownership. The amended regulation, which entered into force in January 2020, represents a significant change in the requirements related to the management of public organisation, primarily in respect of requirements relating to internal control and supervisory boards, to the personnel of internal control organisations and to their work performance, and to the newly established compliance organisations. In addition, Hungary seems to be joining the developed European states through the good practice of public business organisations (Kecskés, 2019).

\section{Conclusion}

In conclusion of the brief overview of the history of 150 years and of the historical experiences, although the brief history Hungary's publicly (state and local government) owned business organisations had its ups and downs, due to the favourable changes implemented in the most recent past - in the field of public finances - gives a forward-looking picture. Initially (in the first half of the 19th century) we could experience that such companies were established with a delay compared to the West, as the state or government, acting as legislator, only recognised its significance considerably later. 


\section{Academic Workshop and Book Reviews}

Due to the favourable fiscal environment after the Compromise, the gap was closed and well capitalised Hungarian state companies of strategic significance and representing national interest were established and rapidly developed for more than fifty years, although naturally, the world historical impacts broke this curve after the Peace Treaty of Trianon, and then again as a result of the 1929 crisis. It can be established that during socialism, an economic approach unfamiliar to Hungarians and inflicted on the country by external force, state farms were by nature extremely different from the public companies that operated before or that have been operating since that period. In the period of privatisation and during the spread of the neoliberal market economy, the significance of public business organisations declined considerably, due to the flawed fiscal and public finance policy characteristic of the period. Proof positive of the close and inalienable relationship between public finances and public companies is the change that took place in this respect.

\section{Notes}

1 Article 1 b) of Act CXXII of 2009 on the frugal operation of business organisations in public ownership.

2 In relation to the books by Lentner, 2019, and on the same topic: Lentner, 2020.

\section{REFERENCES}

Bognár, K. (1994): A Magyar Nemzeti Bank történetéból [From the history of the National Bank of Hungary]. Pénzügyi Szemle, Vol. 39, No. 9, pp. 721-730.

Botos, K. (2007): 1956: gazdasági okok és következmények [Economic reasons and consequences]. Magyar Szemle, Vol. 16, No. 1-2, pp. 43-67.
Domokos, L. (2015): Átláthatóság, elszámoltathatóság, integritás - az etikus közpénzügyi menedzsment három alapelve [Transparency, accountability, integrity - the three principals of ethical public financial management]. Polgári Szemle, Vol. 11, No. 4-6, pp. 13-20.

Germuska, P. (2012): Szocialista csoda? Magyar iparfejlesztési politika és gazdasági növekedés, 1950-1975 [A socialist miracle? Hungarian industry development policy and economic growth]. Századok, Vol. 146, No. 1, pp. 47-78.

Gidai, E. (1996): Gazdasági túlélésünk esélyei és az adósság ára [The chances of our economic survival and the price of debt]. Püski Kiadó, Budapest.

Hamza, G. (2015): Száz évvel ezelôtt hunyt el Széll Kálmán, Magyarország miniszterelnöke [Hundred Years Ago Passed Away Kálmán Széll, Prime Minister of Hungary]. Polgári Szemle, Vol. 11, No. 4-6.

Huszti, E. (2001): Széchenyi István gondolatai a modern magyar hitelélet kialakítására [Thoughts by István Széchenyi on the establishment of modern Hungarian lending]. In: Lentner, Cs. (ed.): Tudományos értékeink [Our scholarly values]. Sopron.

Kecskés, A. (2019): Állami vállalatok és közjogi szervek Írországban [State-owned companies and public organisations in Ireland]. In: Szikora, V. (ed.): Állami vállalatok nemzetközi összehasonlításban [Stat-owned companies in an international comparison]. Magyar Közlöny Lap- és Könyvkiadó, Budapest, pp. 145-158.

Kövér, Gy. (1992): A magyar állampénzügyek történetébôl [From the history of public finances in Hungary.] Pénzügyi Szemle, No. 10-11.

Lentner, Cs. (ed.) (2002): Bankszabályozás [Banking regulation]. Soproni Pénzügyi Szakos Egyetemi Hallgatók Szakkollégiuma Alapítvány, Sopron.

Lentner, Cs. (2016): Rendszerváltás és pénzügypolitika [Change of regime and financial policy]. Akadémiai Kiadó, Budapest.

Lentner, Cs. (2017): Szemelvények a magyar állampénzügyi rendszer fejlődéstörténetébôl [Excerpts from the history of public finances in Hungary]. Pro Publico Bono, No. 2, pp. 84-97.

Lentner, Cs. (2019): A magyar állampénzügyek fejlődéstörténete a dualizmus korától napjainkig. Nyugattól keletre, Kelettól nyugatra [The evolution of public finances in Hungary from Age of Dualism to our day. East from West, west from Asia]. L'Harmattan Kiadó, Budapest. 


\section{Academic Workshop and Book Reviews}

Lentner, Cs. (2020): East of Europe, West of Asia. L'Harmattan Publishing, Paris.

Lentner, Cs.; Szegedi, K. and Tatay, T. (2017): Social Responsibility in the Operation of Central Banks. Financial and Economic Review, Vol. 16, No. 2, pp. 64-85, https://doi.org/10.25201/ fer.16.2.6485.

Matolcsy, Gy. (1998): Sokk vagy kevés? [Too much shock (or too little)?]. Kairosz Kiadó, Budapest.

Matolcsy, Gy. (2016): Economic Balance and Growth. Kairosz Publishing, Budapest.

Milhaupt, C. J. (2020): The State as Owner - China's Experience. Oxford Review of Economic Policy, Vol. 36, No. 2, https://ssrn.com/abstract=3501248.

Papp, T. (2000): A magyar társasági jog fejlôdése [Development of Hungarian corporate law]. Acta Universitatis Szegediensis, Vol. 58, No. 1-41, pp. 409-434.

Perbíró,J. (1950): Gazdaságijog [Economic law]. University coursebook, University of Szeged, Szeged.

Suba, J. (2018): Dunai hajózás és vízirendészet, 1922-1939 [Navigation and waterway police on the Danube, 1922-1939]. In: Emlékkönyv Ốry Károly születésének 85. évfordulója tiszteletére [A book for the 85th birthday of Károly Ôry]. Salutem (6), Szemere Bertalan Magyar Rendvédelem-történeti Tudományos Társaság, Budapest, pp. 141-171.

Szabó, D. (2001): Köztörténet [Public history]. In: Szentpéteri J. and Hargitai, Gy. (eds.): Az Osztrák-Magyar Monarchia. Magyarország múvelôdéstörténete 1867-1918 [The Austro-Hungarian Monarchy. A cultural history of Hungary 18671918]. Kossuth Kiadó, Budapest, pp. 7-94.

Szávai, F. (2017): A Horthy-korszak jóléti állama, eredményei a gazdasági modernizáció tükrében [Welfare state and achievements during Horthy's government in light of the economic modernisation.] Közép-európai Közlemények, Vol. 10, No. 4, pp. 136-151.

Varga, J. (2017): Reducing the Tax Burden and Whitening the Economy in Hungary after 2010. Public Finance Quarterly, Vol. 62, No. 1, pp. 7-21. 